\title{
Mean platelet volume in patients with acute pancreatitis
}

\author{
Akut pankreatit hastalarında ortalama trombosit hacmi \\ Nigar Yılmaz ${ }^{1}$, Orhan Veli Özkan², Sadık Büyükbaşs ${ }^{1}$, Yeşim Can ${ }^{1}$, O. Hasan Öztürkk ${ }^{1}$, \\ Akın Aydoğan², Zafer Yönden ${ }^{1}$ \\ ${ }^{1}$ Department of Biochemistry, Mustafa Kemal University, Faculty of Medicine, Hatay, Turkey \\ ${ }^{2}$ Department of General Surgery, Mustafa Kemal University, Faculty of Medicine, Hatay, Turkey
}

\section{ABSTRACT}

Objectives: Platelet contributed tissue damage and inflammations have been of increased interest. It was previously suggested that platelets have an important role in patients with acute pancreatitis (AP). We aimed to assess the mean platelet volume (MPV) which is described as an indicator of platelet activation and platelet count in patients with AP.

Materials and methods: The study group consisted of 30 patients with AP and 30 control subjects who were matched for age, gender, body mass index (BMI). MPV values and platelet counts were measured on admission.

Results: Mean platelet volume was significantly higher among patients with AP when compared with control group (8.82 \pm 1.33 vs. $7.94 \pm 0.54 \mathrm{fL}$ respectively; $p<0.01)$. Platelet count was significantly lower among AP patients when compared with control group $(223.0 \pm 46.2$ vs. $295.3 \pm 58.9$ $\times 109 / L$ respectively; $p<0.001)$. The level of CRP was significantly higher in patients with AP compared with control group. Platelet and MPV were correlated with serum CRP levels in correlation analysis $(p<0.01 ; r=-0.364, r$ $=0.406$ respectively). We have shown increased MPV, an indicator of platelet activation, in patients with AP. The platelet count was found to be decreased in patients with AP. MPV values and platelet counts were correlated with serum C-reactive protein level that is known as an inflammation marker.

Conclusion: In conclusion, increased MPV level in AP may be a marker for the diagnosis of acute pancreatitis. $J$ Clin Exp Invest 2011; 2 (4): 362-365

Key words: Acute pancreatitis, mean platelet volume, platelet count, platelet activation, inflammation

\section{INTRODUCTION}

Acute pancreatitis (AP) is an inflammatory disease characterized by disturbances of pancreatic microcirculation. ${ }^{1,2}$ The erythrocyte flow patterns

\section{ÖZET}

Amaç: Trombosit ile ilgili doku hasarı ve inflamasyon son zamanlarda ilgi çeken bir konudur. Daha önce de belirtildiği üzere, akut pankreatitli (AP) hastalarda trombosit önemli rol oynamaktadır. Bizim amacımız, AP hastalarda trombosit aktivasyonu ve trombosit sayısının belirteci olarak bildirilen MPV'yi araştırmaktır.

Gereç ve yöntem: Çalışma grubu 30 AP hastası ve 30 kontrol hastasından ibaret olup yaş, cinsiyet ve BMI oranları eşleştirilmiştir. MPV değerleri ve trombosit sayıları ölçüldü.

Bulgular: Akut pankreatit hastalarında MPV değerleri kontrol grubuyla karşılaştırıldığında ileri derecede yüksek bulunmuştur (8.82 \pm 1.33 vs. $7.94 \pm 0.54 \mathrm{fL}$ sırayla; $p$ $<0.01)$. Trombosit sayısı AP hastalarda kontrol grubuyla karşılaştırıldığında anlamlı olarak düşük bulunmuştur (223.0 \pm 46.2 vs. $295.3 \pm 58.9 \times 109 /$ L sırayla; $p<0.001)$. Creaktif protein seviyesi ise AP hastalarında kontrol grupla karşılaştırıldığında anlamlı olarak yüksekti. Korelasyon analizinde trombosit ve MPV değerleri serum CRP değerleriyle korele olduğu görüldü $(p<0.01 ; r=-0.364, r=$ 0.406 sırayla). AP hastalarında trombosit aktivasyonunu gösteren MPV değerinin yüksek olduğu tespit edilmiştir. Trombosit sayısı ise düşük bulunmuştur. İnflamasyon belirteci olarak bilinen CRP seviyesi ise MPV değeri ve trombosit sayıları ile koreledir.

Sonuç: Sonuç olarak, AP hastalarında artmış MPV seviyesi AP'nin teşhisi için bir markır olabilir.

Anahtar kelimeler: Akut pankreatit, MPV, trombosit sayı$\mathrm{SI}$, trombosit aktivasyonu, inflamasyon

and leukocyte-endothelium interaction have role in pathophysiology of AP. ${ }^{3}$ Besides, platelet activation plays an important role in damaging of microcirculation in AP. Although platelet activation is implicated in thrombotic diseases, few reports have showed 
platelet activation in patients with AP. To the best of our knowledge, there are only two studies in the literature about mean platelet volume (MPV) levels in patients with AP4. ${ }^{5}$ The platelet function can be assessed easily by MPV which does not require advanced or expensive technology. ${ }^{6,7}$ In comparison to smaller ones, larger platelets have more granules, aggregate more rapidly with collagen, and release more thromboxane A2 which induces activation of platelets and vasoconstriction. ${ }^{8}$ It was established that coagulation abnormalities occur in AP and they are related to the severity of the disease. ${ }^{9}$ However the platelet function and the role of the coagulation cascade in AP remain obscure. The low levels of platelets have been reported to be associated with severity and prognosis of AP..$^{10}$ The aim of this study was to investigate the platelet indices including MPV and platelet count in patients with AP.

\section{MATERIALS AND METHODS}

The study population consisted of 30 consecutive patients ( 17 females, 13 males) with AP admitted to Mustafa Kemal University hospital. Thirty subjects matched for age, gender, body mass index (BMI) and frequency of concomitant diseases, that were randomly chosen from the patients admitted to outpatient clinic of general surgery department for other diseases served as controls (15 females, 15 males). There was no significant difference between patients with AP (56.9 \pm 20.2 years) and control subjects (49.9 \pm 15.2 years) in terms of the mean age.

Those who did not present any systemic disease and who had normal renal and liver function with no anticoagulant medication history were included in the study. The study was approved by the institutional Ethics Committe of Medical Faculty of Mustafa Kemal University.

\section{Blood sampling}

Blood samples were drawn from the antecubital vein by careful vein puncture with a $21 \mathrm{G}$ sterile syringe without stasis at 08.00-10.00 AM after a fasting period of $12 \mathrm{~h}$. MPV and platelet counts were measured in blood samples, which were collected to dipotassium EDTA tubes before treatment. Whole blood counts and MPV were determined using an autoanalyzer (Beckman Coulter LH 750). Lipid profiles and amilase were assayed by standard methods (colorimetric method, Beckman Coulter LX-20). CRP was assayed by Beckman Coulter image immunochemistry system.

\section{Statistical analysis}

Data were analyzed by using a commercially available statistics software package (SPSS for Win- dows v. 15.0, Chicago, Illinois, USA). Continuous variables from the study groups were reported as mean \pm standard deviation, and categorical variables as percentages. Student's-t-test was performed and multiple comparisons were made using least-squares differences. Correlation between different parameters was assessed using Pearson's coefficient test. To compare age, gender, comorbidity diseases, calcium, phosphorus, total protein, albumin, alkaline phosphatase and parathormon, the Student-t-test were used. Results are presented as mean $\pm S D$ and $p<0.05$ was regarded as statistically significant.

\section{RESULTS}

The knowledge about clinical features of the study and control groups were summarized in Table 1. There were no statistically significant differences between the two groups with respect to age, gender, BMI, levels of triglyceride, total cholesterol, lowdensity lipoprotein (LDL) cholesterol, high-density lipoprotein (HDL), cholesterol, hemoglobin and white blood cell count (WBC). The level of serum amylase was found significantly increased in patients with AP compared to control group ( $p<0.001)$. MPV was significantly higher among AP patients when compared to control group $(8.82 \pm 1.33$ vs. $7.94 \pm 0.54 \mathrm{fL}$ respectively; $p<0.01$ ). Platelet counts were significantly lower among AP patients when compared to control group $(233.0 \pm 46.26$ vs. $295.3 \pm 58.9 \times 109 / \mathrm{L}$ respectively; $p<0.001)$. Platelet counts and MPV were correlated with serum CRP levels $(p<0.01 ; r=$ $-0.364, r=0.406$ respectively) in correlation analysis. The knowledge about MPV, platelet count and CRP level are shown in Table 2.

Table 1. Comparison of the clinical and laboratory characteristics of the patients with acute pancreatitis and controls.

\begin{tabular}{llll}
\hline & AP $(\mathrm{n}=30)$ & $\begin{array}{c}\text { Control } \\
(\mathrm{n}=30)\end{array}$ & $\mathrm{p}$ value \\
\hline Age (years) & $56 \pm 20$ & $49 \pm 15$ & 0.29 \\
Sex $(\mathrm{F} / \mathrm{M})$ & $17 / 13$ & $15 / 15$ & 0.90 \\
$\mathrm{BMI}\left(\mathrm{kg} / \mathrm{m}^{2}\right)$ & $26.7 \pm 4.1$ & $24.6 \pm 3.2$ & 0.10 \\
Total cholesterol (mmol/L) & $2.03 \pm 0.69$ & $2.06 \pm 0.36$ & 0.81 \\
Triglycerides $(\mathrm{mmol} / \mathrm{L})$ & $1.87 \pm 0.62$ & $1.47 \pm 0.63$ & 0.16 \\
LDL-cholesterol $(\mathrm{mmol} / \mathrm{L})$ & $1.15 \pm 0.18$ & $1.14 \pm 0.11$ & 0.62 \\
HDL-cholesterol $(\mathrm{mmol} / \mathrm{L})$ & $10.47 \pm 0.14$ & $0.49 \pm 0.2$ & 0.72 \\
WBC (×109/L) & $11.4 \pm 3.6$ & $10.5 \pm 6.8$ & 0.54 \\
Hemoglobin $(\mathrm{g} / \mathrm{dL})$ & $12.5 \pm 2.3$ & $11.9 \pm 2.1$ & 0.32 \\
\hline
\end{tabular}

AP: Acute pancreatitis, F/M: female to male, BMI: body mass index, WBC: white blood cell. $p$ value is for comparison between control and study population. 
Table 2. Comparison of the platelet indices of the patients with acute pancreatitis and controls.

\begin{tabular}{llll}
\hline & AP $(n=30)$ & $\begin{array}{l}\text { Controls } \\
(n=30)\end{array}$ & P value \\
\hline Platelet count $\left(\times 10^{9} / \mathrm{L}\right)$ & $223.0 \pm 46.26^{\mathrm{a}}$ & $295.3 \pm 58.9<0.001$ \\
& $8.82 \pm 1.33^{\mathrm{b}}$ & $7.94 \pm 0.54$ & $<0.01$ \\
MPV $(\mathrm{fL})$ & $9.57 \pm 5.75^{\mathrm{c}}$ & $0.86 \pm 0.55$ & $<0.001$ \\
$\begin{array}{l}\text { C-reactive protein, } \\
\text { mg/dl }\end{array}$ & & & \\
\hline
\end{tabular}

AP: Acute pancreatitis, MPV: mean platelet volume. ${ }^{\mathrm{a}}$ : vs. control group, b: vs. control group, c: vs. control group

\section{DISCUSSION}

Recent advances have revealed that platelets contribute to disturbance of the local microcirculation in AP. ${ }^{11}$ Activated platelets produce oxygen radicals and proinflammatory mediators including tromboxane A2, platelet factor IV, serotonin, leukotrienes and cause the microvascular disturbances. ${ }^{12,13}$ The cascade of coagulation events seems to play a critical role in the pathogenesis of AP. ${ }^{9}$ It was previously suggested that platelet count is a sensitive parameter for assessing the prognosis in AP. ${ }^{14}$ Metabolical and enzymatic activities of larger platelets have previously been shown to be greater than those of smaller platelets. In addition, larger platelets were reported to have higher prothrombotic potential. ${ }^{15}$ Increased platelet size is more active in hemostasis, contain more granules and adhesion receptors and release vasoconstrictor mediators. Increased platelet activation leads to activation of coagulation and coagulation affects. ${ }^{9}$ It was indicated that coagulation, vasoconstriction, inadequate perfusion are significant events in the progression of AP..$^{16}$ The platelet function is assessed by MPV which was determined by a simple and easy method. MPV shows the platelet production rate and stimulation. ${ }^{17}$ In the present study, we analyzed MPV, an indicator of platelet activation in patients with AP. The level of MPV was found to be elevated in several diseases including Familial Mediterranean Fewer, acute ischemic stroke and Rheumatoid arthritis. ${ }^{18-20}$ In consistence with these studies, we also found that MPV was higher in AP patients than in control group. Previous studies have shown that microvascular occlusions can cause platelet activation. Increased platelet activation is well established in Sickle Cell Disease which is characterized by microvascular occlusion. However, decreased MPV was observed in Sickle Cell Disease. Mohan et al. speculated that these MPV may not be a suitable marker of platelet activation in Sickle Cell Anemia. ${ }^{21}$ In contrast to this study, we found that MPV was elevated in patients with AP. Recently; Abdulla et al. investigated plate- let activation in AP. They showed that platelets play an important role in $\mathrm{AP}$, which is characterized by an impairment of microcirculation due to activation of coagulation and inflammatory cascade systems. Yuksel et al. indicated that decreased MPV may be an indicator for increased diseases activity including ulcerative colitis, crohn's disease, rheumatoid arthritis, ankylosing spondylitis..$^{20,23,27}$

Therefore, increased MPV can be accepted as simple marker of platelet activation in AP. Platelet size is associated with platelet activation, also high MPV level may result of consumption of small platelets and a compensatory production of larger reticulated platelets during AP. ${ }^{24,28}$ Therefore MPV is preferred using as a marker of platelet activation and platelet function. In this study, platelet count was significantly lower among patients with AP when compared with control group. This lower platelet count in patients with AP might be due to using of the platelets. Assessment of AP severity is routinely done by measuring level of CRP, which is a nonspecific inflammatory marker that is synthesized by the hepatocytes. ${ }^{25}$ We also found that serum CRP levels were elevated in patients with AP. It has been corrected that an inflammation condition may accompany and possible be related to AP. ${ }^{31}$ MPV and platelet counts were correlated with serum CRP level. The increased level of MPV should alert clinicians and warrant early evaluation. It was reported that inflammatory mediators increase platelet production and newly protected platelets found more thrombogenic. ${ }^{22}$ In previous study, MPV was found associated with high grade inflammation, largely influenced by the intensity of inflammation. ${ }^{26} \mathrm{MPV}$ levels were also shown to be lower in patients with high-grade inflammatory diseases, such as Familial Mediterranean Fever or active Rheumatoid Arthritis. This trend reverses during the course of anti-inflammatory therapy. ${ }^{20,30}$

MPV had found no significant direct correlations with serum triglyceride, total cholesterol, LDL cholesterol, HDL cholesterol. Measuring the serum amylase level is helpful in diagnosing AP. However, it was reported that AP is needed a guidelines to be managed. ${ }^{29}$ MPV may guide to identify high-risk patients in AP and other disturbed microcirculation related disease. MPV may also become a prognostic factor in patients with AP.

In conclusion, we have shown that MPV was significantly elevated in patients with AP and platelet count was decreased in patients with AP. While platelet count shows negative correlation with the level of CRP, which is an inflammatory marker, it shows positive correlation with MPV levels. More 
rigorously designed future studies are required to precisely investigate the role of MPV regarding the diagnosis, prognosis and etiopathogenesis of AP and to justify its potential use in clinical practice.

\section{REFERENCES}

1. Cuthbertson CM, Christophi C. Disturbances of the microcirculation in acute pancreatitis. $\mathrm{Br} J$ Surg 2006;93(5):518-30.

2. Uhlmann D, Ludwig J, Geissler F, Tannapfel A, Hauss $\mathrm{J}$, Witzzigmann $\mathrm{H}$. Importance of microcirculatory disturbances in the pathogenesis of pancreatitis. Zentralbl Chir 2001;126(11):873-8.

3. Zhang XP, Chen L, Hu QF, et al. Effects of large dose of dexamethasone on inflammatory mediators and pancreatic cell apoptosis of rats with severe acute pancreatitis. World J Gastroenterol 2007;13(41):5506-11.

4. A. Abdulla, D. Awla, H. Hartman, M. Rahman, B. Jeppsson, S. Regner and $\mathrm{H}$. Thorlacius. Role of platelets in experimental acute pancreatitis. British Journal of Surgery 2011;98(1):93-103.

5. Mimidis K, Papadopoulos V, Kotsianidis J, et al. Alterations of platelet function, number and indexes during acute pancreatitis. Pancreatology 2004;4(1):22-7.

6. Park Y, Schoene N, Haris W. Mean platelet volume as an indicator of platelet activation: Methodological issues. Platelets 2002;13(5-6):301-6.

7. Boos CJ, Lip GY. Assesment of mean platelet volume in coronary artery disease-What does it mean? Thromb Res 2007;120(1):11-3.

8. Ranjith MP, Divya R, Mehta VK, Krishnan MG, KamaIRaj R, Kavishwar A. Significance of platelet volume indices and platelet count in ischaemic heart disease. J Clin Pathol 2009;62(9):830-3.

9. Kakafika A, Papadopoulos V, Mimidis K, Mikhailidis DP. Coagulation, platelets, and acute pancreatitis. Pancreas 2007;34(1):15-20.

10. Maeda K, Hirota M, Ichihara A, Ohmuraya M, Hashimoto D, Sugita H, Takamori H, Kanemitsu K, Baba $\mathrm{H}$. Applicability of disseminated intravascular coagulation parameters in the assessment of the severity of acute pancreatitis. Pancreas 2006;32(1):87-92.

11. Uhlmann D, Lauer H, Serr F, Witzigmann H. Microvasc Res. Pathophysiological role of platelets and platelet system in acute pancreatitis. Microvasc Res 2008;76(2):114-23.

12. Weyrich AS, Elstad MR, McEver RP, et al. Activated platelets signal chemokine synthesis by human monocytes. J Clin Invest 1996 15;97(6):1525-34.

13. Bouchard BA, Tracy PB. Platelets, leukocytes, and coagulation. Curr Opin Hematol 2001;8(5):263-9.

14. Fujimura $Y$, Hirota $M$, Ichihara $A$, Takamori $H$, Baba $H$. Pancreas 2008;37(2):225-7.

15. Uhlmann D, Lauer H, Serr F, Witzigmann H. Pathophysiological role of platelets and platelet system in acute pancreatitis. Microvasc Res 2008;76(2):114-23.
16. Abdulla A, Awla D, Hartman $H$, et al. Role of platelets in experimental acute pancreatitis. $\mathrm{Br} \mathrm{J}$ Surg 2011;98(1):93-103

17. Vagdatli E, Gounari E, Lazaridou E, Katsibourlia E, Tsikopoulou F, Labrianou I. Platelet distribution width: a simple, practical and specific marker of activation of coagulation. Hippokratia 2010;14(1):28-32.

18. Makay B, Türkyilmaz Z, Unsal E. Mean platelet volume in children with familial Mediterranean fever. Clin Rheumatol 2009;28(8):975-8.

19. Mayda-Domaç F, Misirli H, Yilmaz M. Prognostic role of mean platelet volume and platelet count in ischemic and hemorrhagic stroke. J Stroke Cerebrovasc Dis 2010;19(1):66-72.

20. Yazici S, Yazici M, Erer B, e al. The platelet indices in patients with rheumatoid arthritis: mean platelet volume reflects disease activity. Platelets 2010;21(2):122-5.

21. Mohan JS, Lip GY, Bareford D, Blann AD. Platelet Pselectin and platelet mass, volume and component in sickle cell disease: relationship to genotype. Thromb Res 2006;117(6):623-9.

22. Gasparyan AY. Platelets in inflammation and thrombosis. Inflamm Allergy Drug Targets 2010;9(5):319-21.

23. Francis RB Jr. Platelets, coagulation, and fibrinolysis in sickle cell disease: their possible role in vascular occlusion. Blood Coagul Fibrinolysis 1991;2(2):34153

24. Cay S, Biyikoglu F, Cihan G, Korkmaz S. Mean platelet volume in patients with cardiac syndrome X. J Thromb Thrombolysis 2005;20:175-78

25. Papachristtou GI, Whitcomb DC. 'Inflammatory markers of disease severity in acute pancreatitis'. Clin Lab Med 2005;25(1):17-37

26. Kisacik B, Tufan A, Kalyoncu $U$, et al. Mean platelet volume (MPV) as an inflammatory marker in ankylosing spondylitis and rheumatoid arthritis. Joint Bone Spine 2008;75(3):291-4.

27. Yüksel O, Helvaci K, Başar O, et al. An overlooked indicator of disease activity in ulcerative colitis: mean platelet volume. Platelets 2009;20(4):277-81.

28. Gasparyan AY, Ayvazyan L, Mikhailidis DP, Kitas GD. Mean platelet volume: a link between thrombosis and inflammation? Pancreatology 2005;5(2-3):132-44.

29. Stevens T, Parsi MA, Walsh RM. Acute pancreatitis: problems in adherence to guidelines. Cleve Clin $\mathrm{J}$ Med 2009;76(12):697-704.

30. Gür A, Nas K, Çevik R, Erdoğan F, Karakoç M. Comparison of Arthritis of impact measurement scale (aims) and Health assessment Questionnaire (Haq) according to onset age of Rheumatoid arthritis. Dicle Tıp Dergisi 2000; 27(2):61-8

31. Dursun M, Yılmaz Ş, Canoruç F, Batum S, Kaplan A. Akut pankreatitli olgularımızın analizi. Dicle Tıp Dergisi $2001 ; 28(2): 19-27$. 